\title{
Plasmids in the Genus Bifidobacterium
}

\author{
By BARBARA SGORBATI, ${ }^{*}$ VITTORIO SCARDOVI ${ }^{1}$ AND \\ DONALD J. LEBLANC ${ }^{2}$ \\ ${ }^{1}$ Istituto di Microbiologia Agraria, Università di Bologna, Itály \\ ${ }^{2}$ Laboratory of Molecular Microbiology, National Institute of Allergy and Infectious Diseases, \\ National Institutes of Health, Frederick, Maryland 21701, U.S.A.
}

(Received 10 November 1981; revised 9 February 1982)

\begin{abstract}
A total of 1461 bacterial isolates, representing 24 different species of the genus Bifidobacterium, were examined for the presence of plasmid DNA. Approximately $20 \%$ of the isolates contained detectable plasmids, but only four species were represented: $B$. longum, the predominant bifid species in the human intestine; $\boldsymbol{B}$. globosum, the most common in animals; and $\boldsymbol{B}$. asteroides and $B$. indicum, species found exclusively in the intestines of western and asiatic honey bees, respectively. Multiple plasmids were common among isolates of $B$. longum and $B$. asteroides, while all plasmid-bearing isolates of $B$. globosum and $60 \%$ of $B$. indicum isolates contained only one plasmid each. Certain multiple plasmid profiles were predominant among the $B$. longum and $B$. asteroides isolates.
\end{abstract}

\section{INTRODUCTION}

Plasmids have been observed in representatives of virtually every bacterial genus examined for their presence, and contribute to the genetic and evolutionary potential of these microorganisms. Several categories of phenotypic trait, such as antibiotic resistance, toxin and bacteriocin production, modification of bacterial virulence and an ever-increasing number of metabolic capabilities, are often associated with plasmids (Falkow, 1975; Broda, 1979). These extrachromosomally determined properties can be widely disseminated among bacterial populations by natural transfer mechanisms, such as transformation, transduction and conjugation (Falkow, 1975; Broda, 1979). Exclusive of their role as carriers and transporters of genetic information, plasmids can also provide a means of strain typing (Davies et al., 1981), or molecular fingerprinting, for following the flow of specific bacteria through host populations.

The presence of plasmids is common among natural isolates of bacterial species which inhabit the intestinal tracts of humans and animals. In fact, the isolation of Enterobacteriaceae or enterococci which are plasmid-less is rare, and most natural isolates have multiple plasmids. Recent reports have described the presence of plasmids in the genus Bacteroides, a major component of the intestinal flora (Privitera et al., 1979; Tally et al., 1979; Welch et al., 1979). The bifidobacteria are also normal constituents of the intestinal flora of man, various animals and honey bees (Mitsuoka \& Kaneuchi, 1977; Scardovi, 1981). Most species are found almost exclusively in the intestinal tract of the host organism, where their presence in high numbers $\left(10^{9}-10^{10}\right.$ in humans; Mitsuoka \& Kaneuchi, 1977) is thought to be beneficial (Poupard et al., 1973). To our knowledge, there is no published information regarding plasmids in this genus.

We have surveyed the genus Bifidobacterium for the presence and distribution of plasmids. A total of 1461 strains, from the Collection of the Institute for Agricultural Microbiology of Bologna University, representing 22 different species and two DNA homology groups were examined. The results of this survey, as well as some preliminary data on the potential taxonomic and ecological significance of plasmid profiles in some of the species, are presented in this communication. 


\section{METHODS}

Bacterial strains and culture conditions. Strains of Bifidobacterium spp. were isolated from a variety of sources and have been identified by DNA-DNA hybridization, except for a few from honey bees. Most isolates, nearly 1200 , have also been characterized by isozyme electrophoresis (Scardovi et al., 1979). A large number of fermentative biotypes were included among the strains of most species, as well as urease-positive and urease-negative strains of the species B. suis (Matteuzzi \& Crociani, 1973). Because of the possible loss of plasmids by repeated subculturing, freeze-dried preparations from the first cultures following isolation were used in the plasmid analyses.

Most species were grown on trypticase/phytone/yeast extract medium of the following composition: trypticase (BBL), $0.8 \mathrm{~g}$; phytone (BBL), $0.3 \mathrm{~g}$; yeast extract (Difco), $0.25 \mathrm{~g}$; glucose, $1.0 \mathrm{~g} ; \mathrm{K}_{2} \mathrm{HPO}_{4}, 0.15 \mathrm{~g} ; \mathrm{MgCl}_{2}, 0.05 \mathrm{~g}$; cysteine. $\mathrm{HCl}, 0.05 \mathrm{~g}$; Tween $80,0.1 \mathrm{ml}$; distilled water, $100 \mathrm{ml} ; \mathrm{pH}$ adjusted to $6.5-6.7$. Bifidobacterium pullorum and $B$. coryneforme isolates were grown on MRS medium (DeMann et al., 1960).

Cylindrical vessels $(35 \times 160 \mathrm{~mm})$ were filled with medium $(90 \mathrm{ml})$, sterilized at $110^{\circ} \mathrm{C}$ for $20 \mathrm{~min}$, and inoculated with culture $(10 \mathrm{ml})$. Incubation was at $38-39^{\circ} \mathrm{C}$ under a $\mathrm{CO}_{2} / \mathrm{N}_{2}$ atmosphere with a palladium catalyst (BBL, Gas-Pak). One or two culture vessels were used for each screening, depending on cell yield. When large quantities of cells were required, flasks ( 1 litre) almost completely filled with medium were inoculated as soon as possible after autoclaving. Sodium bicarbonate solution $(10 \%, \mathrm{w} / \mathrm{v})$ was filter-sterilized and added to the medium $\left(3 \mathrm{ml} \mathrm{1}^{-1}\right)$, and the flasks incubated under air. Cells were harvested in exponential or early stationary phase.

Plasmid analyses. The rapid screening technique of LeBlanc \& Lee (1979), developed for streptococci, was suitable for bifidobacteria and used here for all plasmid analyses. Agarose gel electrophoresis was performed according to Meyers et al. (1976) using vertical slab gels $(14 \times 12 \times 0.3 \mathrm{~cm})$ with $0.8 \%(\mathrm{w} / \mathrm{v})$ agarose (BioRad, standard $10 \mathrm{w}-\mathrm{m}_{\mathrm{r}}$ ) using combs giving 4 or $8 \mathrm{~mm}$ wells. Plasmid DNA from Escherichia coli strain V517 (Macrina et al., 1978), isolated by the above procedure, was used as a source of eight covalently closed circular (CCC) size markers of $1 \cdot 4,1 \cdot 8,2 \cdot 0,2 \cdot 6,3 \cdot 4,3 \cdot 7,4 \cdot 8$ and 36 MDal. Alternatively, a plot of $E$. coli V517 CCC DNA on log-log paper was used to determine the CCC equivalents of linear HindIII-digested $\lambda$ DNA fragments. This provided six additional CCC size markers at $1 \cdot 9,2 \cdot 2,3 \cdot 5,4 \cdot 4,5 \cdot 5$ and $8 \cdot 5 \mathrm{MDal}$.

\section{RESULTS AND DISCUSSION}

We have examined nearly 1500 bacterial isolates belonging to the genus Bifidobacterium for the presence of plasmid DNA. Approximately $21 \%$ of the plasmid-enriched lysates from these isolates produced one or more extrachromosomal DNA bands when electrophoresed in agarose gels. However, among the 303 plasmid-containing isolates only four species of Bifidobacterium were represented, as shown in Table 1 . The variety of plasmid profiles observed among these four species is presented schematically in Figs 1,2 and 5. Failure to detect plasmids in the remaining species and homology groups may be due to (1) the absence of plasmids in certain species, (2) the inability to isolate certain classes of plasmids by the procedure employed, or (3) examination of too few representatives of some species.

Our screening results suggested that particular DNA banding profiles appeared to predominate within each of the four species harbouring detectable plasmids. Since plasmid profiles may have taxonomic value as well as providing useful ecological and evolutionary information, we have begun a systematic analysis of the plasmids in these species.

\section{Plasmid profiles of $B$. longum isolates}

Seven species of Bifidobacterium are listed in Table 1 as having humans as their primary host, and three of these, $B$. longum, $B$. breve and $B$. infantis, constitute the major portion of the bifidobacterial flora of the faeces of newborn infants. Plasmid bands were detected among isolates of only one of these species, $B$. longum. The above three species are very closely related: DNA homology between $B$. longum and $B$. infantis is $65-80 \%$, and $B$. breve shows $50-75 \%$ homology with both (Scardovi et al., 1979; Sgorbati, 1979). Furthermore the boundaries between $B$. longum and $B$. infantis seem to vanish if one considers the strains termed 'intermediates' (Table 1) isolated from calf faeces, which, being more than $80 \%$ related by DNA homology to both $B$. infantis and $B$. longum, cannot be assigned to either species (Scardovi et al., 1979). Furthermore, most of the strains of $B$. longum and $B$. infantis studied here have been isolated from the same faecal specimens. From 186 isolates of $B$. longum obtained from human adult and infant faeces, plasmids were observed in 127 (about $70 \%$ ), all from infants, and 125 of these were examined in detail. Thirteen different profiles, each consisting of two to seven plasmid bands, 
Table 1. Species of Bifidobacterium examined for the presence of plasmid DNA

\begin{tabular}{|c|c|c|c|c|}
\hline & & & No. of & $\mathrm{f}^{\text {isolates: }}$ \\
\hline Host & Species & Sources of isolates studied* & Studied & $\begin{array}{l}\text { Containing } \\
\text { plasmids }\end{array}$ \\
\hline Humans & B. longum & Infant and adult faeces & 186 & 127 \\
\hline & B. dentium & $\begin{array}{l}\text { Dental caries; infant and adult faeces; vagina; } \\
\text { rabbit faeces; lung abscesses, pleural fluid and } \\
\text { appendices of humans }\end{array}$ & 140 & 0 \\
\hline & B. pseudocatenulatum & Infant and calf faeces, sewage & 120 & 0 \\
\hline & B. breve & Infant faeces; human vagina; calf faeces & 106 & 0 \\
\hline & B. infantis & Infant faeces; human vagina & 63 & 0 \\
\hline & B. catenulatum & Infant and adult faeces; sewage & 41 & 0 \\
\hline & B. bifidum & Infant and calf faeces & 39 & 0 \\
\hline Animals & B. globosum $\dagger$ & $\begin{array}{l}\text { Rat, rabbit and calf faeces; rumen of cattle; } \\
\text { chicken, lamb and piglet faeces; sewage; } \\
\text { infant faeces }\end{array}$ & 129 & 29 \\
\hline & B. thermophilum & Rumen of cattle; sewage; piglet and calf faeces & 74 & 0 \\
\hline & B. animalis & Rabbit, rat and chicken faeces; sewage & 24 & 0 \\
\hline & B. suis & Piglet faeces & 22 & 0 \\
\hline & B. boum & Rumen of cattle; piglet faeces & 22 & 0 \\
\hline & B. magnum & Rabbit faeces & 16 & 0 \\
\hline & B. choerinum & Piglet faeces; sewage & 15 & 0 \\
\hline & B. cuniculi & Rabbit faeces & 7 & 0 \\
\hline & B. pullorum & Chicken faeces & 3 & 0 \\
\hline & B. pseudolongum & Pig, chicken and mouse faeces & 3 & 0 \\
\hline Animals and & B. adolescentis & Sewage; rumen of cattle; adult human faeces & 54 & 0 \\
\hline humans & $\begin{array}{l}\text { B. infantis-B. longum } \\
\text { 'intermediates' }\end{array}$ & Calf faeces & 45 & $\mathbf{0}$ \\
\hline & B. angulatum & Sewage; adult human faeces & 6 & 0 \\
\hline Honey bees & B. asteroides & Bee intestine & 225 & 74 \\
\hline & B. indicum & Bee intestine & 106 & 73 \\
\hline & B. coryneforme $\dagger$ & Bee intestine & 8 & 0 \\
\hline & $\begin{array}{l}\text { DNA homology } \\
\text { groups } \ddagger\end{array}$ & & & \\
\hline & 'subtile' & Sewage & 5 & 0 \\
\hline & 'minimum' & Sewage & 2 & 0 \\
\hline
\end{tabular}

* The sources of isolates are indicated in order of decreasing number of strains isolated therefrom.

$\dagger$ Species not included in the Approved Lists of Bacterial Names (Skerman et al., 1980).

$\ddagger$ Groups of strains distinguished primarily from all other bifidobacteria on the basis of their DNA homology, but not currently proposed as new species (Scardovi \& Trovatelli, 1974).

within a size range of 1.25 to $9.5 \mathrm{MDal}$, were observed (Fig. 3). Three of these, A1, A2 and A3, were produced by $65 \%$ of the plasmid-containing isolates (Table 2 and Fig. 1). In several instances where the profiles appeared to be identical, plasmid preparations were electrophoresed side by side on the same gel to confirm their identical sizes (data not shown). With the exception of profiles $\mathrm{A} 1, \mathrm{~A} 2$ and $\mathrm{A} 3$, together with profile $\mathrm{E}$, which was common to isolates obtained from two different faecal samples, each of the remaining profiles appeared in isolates from only one sample.

Profiles E and A1, each with two plasmid bands, and A2 and A3, each with four bands, were observed in isolates from 2, 7,9 and 6 different faecal samples respectively. Given the size of the plasmids in these isolates, and the number in each profile (particularly profiles A2 and A3), it seems unlikely that they have been transferred to the strains from each of the different faecal samples. More probably, these data suggest that a limited number of $B$. longum strains have been disseminated among the various infants from which the samples were obtained.

For the most part, the isolates from each faecal sample produced only one of the 13 plasmid profiles common to this species. There were only three exceptions among the 30 samples 


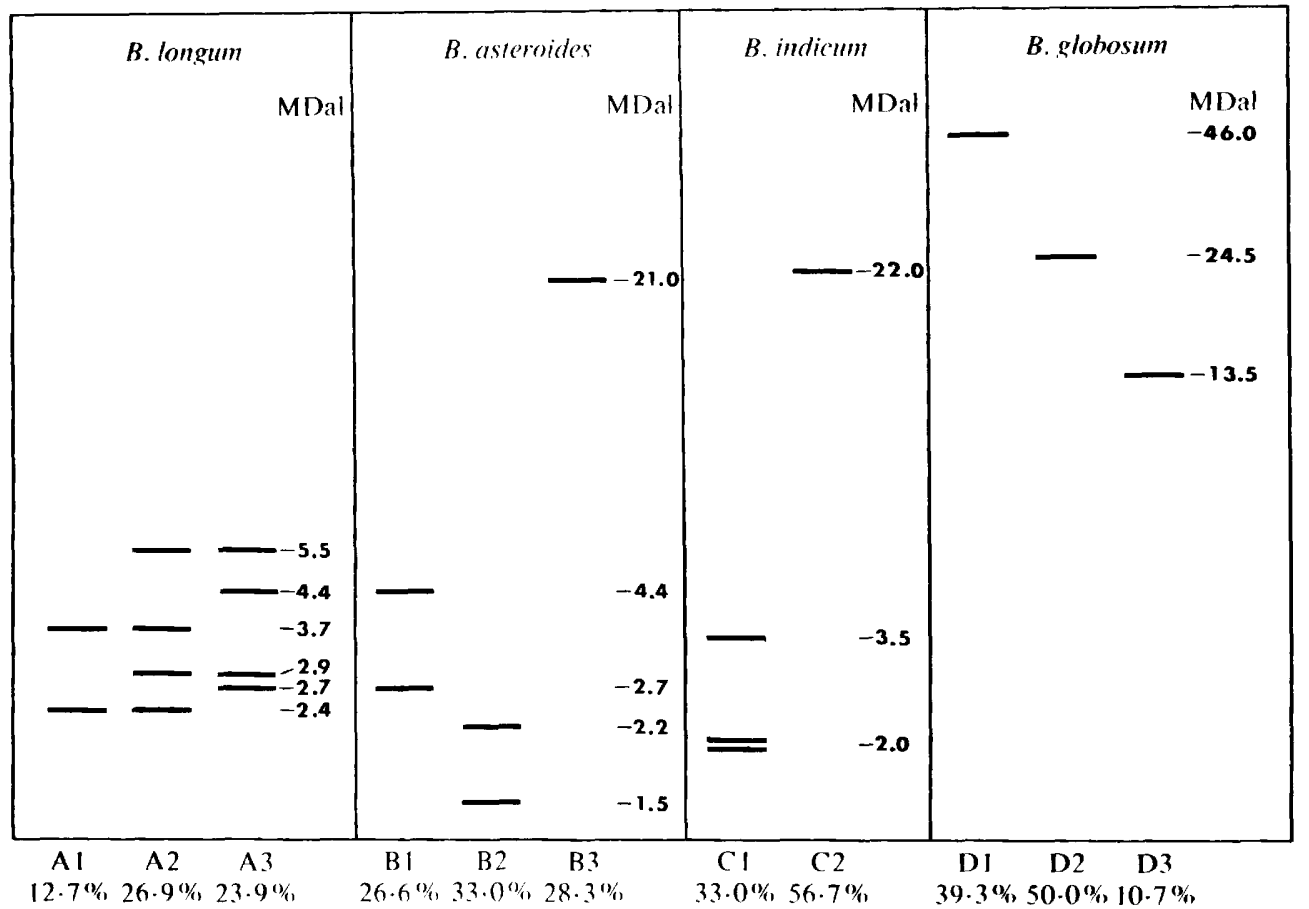

Fig. 1. Diagrammatic representation of the plasmid profiles most frequently found in four species of the genus Bifidobacterium. The letters at the bottom refer to the different plasmid profiles and percentage values represent the proportion of the strains in which each profile was found.

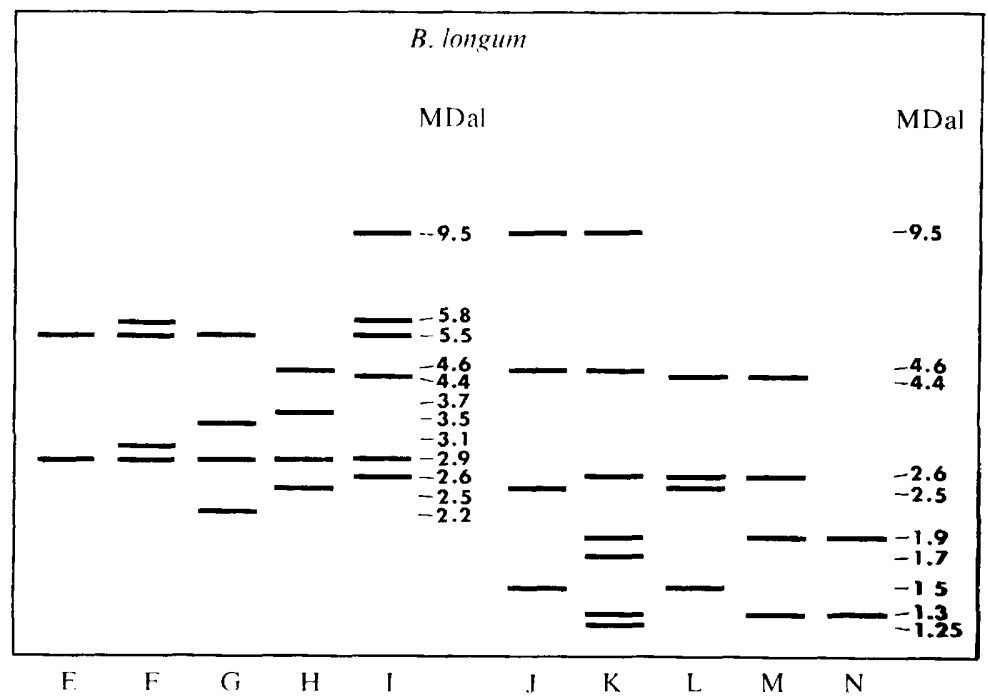

Fig. 2. Diagrammatic representation of the plasmid profiles (indicated by letters) less frequently found in $B$. longum.

examined, samples 1, 5 and 6 , each of which yielded isolates whose plasmid profiles fell into two different groups (Table 2).

\section{Plasmids in B. globosum}

Of the Bifidobacterium spp. listed in Table 1, 10 are found almost exclusively in the intestines of animals. Plasmids were detected in only one of these, B. globosum. However, with the possible 


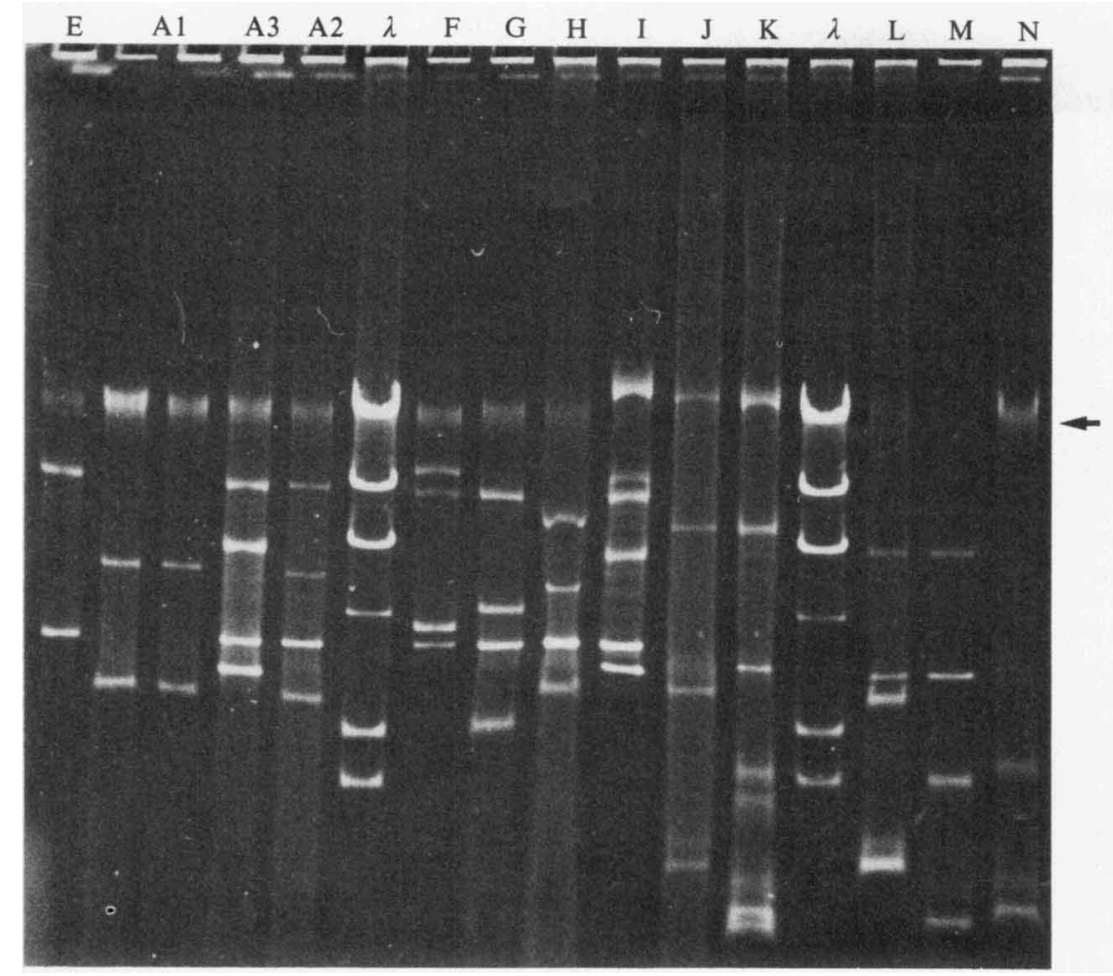

Fig. 3. Agarose gel electrophoresis of plasmids from strains of $B$. longum. Letters above the lanes refer to plasmid profiles used in Table 2 and Figs 1 and 2 . The strains used were: $B$. longum E, B2192; Al (left), B2352; A1 (right), B1678; A3, B2399; A2, B2088; F, B1433; G, B2640; H, B2349; I, B1835; J, B1393; K, B1990; L, B1319; M, B1694; N, B2577. $\lambda$, lanes containing HindIII-restricted phage $\lambda$ DNA. Residual chromosomal DNA is arrowed.

exception of $B$. thermophilum, it is likely that too few isolates of the other species were examined to permit any conclusions regarding the presence or absence of plasmid DNA.

The species B. globosum (Scardovi et al., 1969) is not included in the Approved Lists of Bacterial Names (Skerman et al., 1980), having been considered by Rogosa (1974) as identical with B. pseudolongum (Mitsuoka, 1969). Scardovi et al. (1979) are of the opinion that, on account of differences in $\mathrm{G}+\mathrm{C}$ content of their DNA (about $3 \%$ ) and extent of DNA homology (about $70 \%$ ), the two species should be considered distinct.

A number $(22 \%)$ of the $B$. globosum isolates examined contained extrachromosomal DNA. Unlike the profiles observed in $B$. longum, which exhibited between two and seven plasmid bands, only a single band was detectable in each of the 29 plasmid-containing isolates of $B$. globosum, and a total of only three different sizes were seen (D1, D2 and D3; Table 3, Figs 1 and 4). A $46 \mathrm{MDal}$ plasmid was present in 11 isolates obtained from faecal samples of rats, rabbits and chickens, the rumen of cattle, and sewage. Thirteen isolates from rat, calf and lamb faeces, and sewage, harboured a single 24.5 MDal species. One isolate each from rat, calf and lamb faeces, and from cattle rumen, had a 13.5 MDal plasmid.

It is not known whether plasmids of the same size are identical, nor whether there is any homology between the plasmids of different sizes. All three of the plasmid classes in B. globosum are large enough to code for conjugative functions. Thus, it will be difficult to determine whether specific strains, or their plasmids, are being disseminated among the various animal species.

The species $B$. longum and $B$. globosum represent the predominant species isolated from the intestinal tracts of humans and animals respectively (Reuter, 1963-64; Mitsuoka \& Kaneuchi, 1977; Scardovi, 1981). The distinction between 'human' and 'animal' species has been based on ecological and immunological data (Sgorbati, 1979). It appears that $B$. longum and B. globosum can also be readily distinguished on the basis of their plasmid complements. 
Table 2. Plasmid profiles of $B$. longum isolates

All isolates were obtained from 30 samples of infant faeces. Plasmid profiles are shown in Figs 1,2 and 3.

\begin{tabular}{|c|c|c|c|c|c|c|c|c|c|c|c|c|c|c|}
\hline \multirow{2}{*}{$\begin{array}{c}\text { Sample } \\
\text { no. }\end{array}$} & \multirow{2}{*}{$\begin{array}{l}\text { No. of plasmid- } \\
\text { containing } \\
\text { isolates }\end{array}$} & \multicolumn{13}{|c|}{ No. of isolates with profile: } \\
\hline & & Al & $\mathrm{A} 2$ & $\mathrm{~A} 3$ & $\mathrm{E}$ & $\mathrm{F}$ & $\mathrm{G}$ & $\mathrm{H}$ & $\mathrm{I}$ & $\mathbf{J}$ & $\mathrm{K}$ & $\mathrm{L}$ & $\mathbf{M}$ & $\mathrm{N}$ \\
\hline 1 & 7 & 1 & 6 & . & . & . & • & $\cdot$ & . & . & . & - & - & • \\
\hline 5 & 6 & 1 & 5 & $\cdot$ & $\cdot$ & . & · & · & . & . & • & - & . & • \\
\hline $6^{*}$ & 4 & 2 & · & $\cdot$ & $\cdot$ & . & . & 2 & . & . & • & - & • & - \\
\hline 2 & 2 & 2 & . & . & . & . & . & . & . & . & . & - & . & - \\
\hline $3^{*}$ & 2 & 2 & . & . & . & . & . & . & . & . & - & - & . & . \\
\hline $4^{*}$ & 2 & 2 & . & $\cdot$ & · & . & . & . & . & . & · & - & . & . \\
\hline $7^{*}$ & 6 & 6 & . & $\cdot$ & . & . & . & . & . & . & - & - & - & - \\
\hline 8 & 2 & . & 2 & $\cdot$ & . & . & . & • & . & . & - & . & . & - \\
\hline 9 & 1 & $\cdot$ & 1 & $\cdot$ & . & . & . & • & . & . & - & - & . & . \\
\hline 10 & 1 & . & 1 & $\cdot$ & $\cdot$ & . & · & $\cdot$ & . & . & - & - & . & · \\
\hline 11 & 6 & $\cdot$ & 6 & $\cdot$ & . & . & . & · & . & . & - & . & - & - \\
\hline 12 & 4 & $\cdot$ & 4 & $\cdot$ & · & . & - & · & . & • & - & . & - & - \\
\hline 13 & 9 & $\cdot$ & 9 & $\cdot$ & · & . & - & . & . & . & · & - & . & . \\
\hline 14 & 1 & $\cdot$ & 1 & $\cdot$ & · & . & · & . & . & . & . & - & - & - \\
\hline 15 & 3 & $\cdot$ & . & 3 & · & . & - & . & . & . & . & . & . & - \\
\hline 16 & 6 & . & . & 6 & · & . & . & . & . & . & - & . & - & - \\
\hline 17 & 9 & $\cdot$ & . & 9 & · & . & . & . & . & . & . & . & . & - \\
\hline 18 & 3 & $\cdot$ & . & 3 & · & . & . & . & . & . & - & . & . & - \\
\hline $19^{*}$ & 4 & . & . & 4 & . & . & • & . & . & . & - & . & - & - \\
\hline $20^{*}$ & 5 & . & - & 5 & · & . & . & . & • & . & . & - & . & . \\
\hline $21^{*}$ & 4 & . & . & . & 4 & . & . & . & . & . & . & . & . & . \\
\hline 22 & 2 & . & . & . & 2 & . & . & . & . & . & . & . & . & . \\
\hline 23 & 7 & . & . & . & . & 7 & . & . & . & . & . & . & . & . \\
\hline 24 & 10 & . & . & . & . & . & 10 & . & . & . & . & . & . & . \\
\hline 25 & 1 & . & . & . & . & . & . & . & 1 & . & . & . & . & . \\
\hline 26 & 1 & . & . & . & . & . & . & . & . & 1 & . & . & . & . \\
\hline $27^{*}$ & 3 & . & . & . & . & . & . & . & . & . & 3 & . & . & . \\
\hline 28 & 5 & . & . & $\cdot$ & . & . & . & . & . & . & . & 5 & - & - \\
\hline 29 & 6 & . & . & . & . & . & . & . & . & . & . & . & 6 & . \\
\hline 30 & 3 & · & . & $\cdot$ & $\cdot$ & . & . & . & . & . & . & . & . & 3 \\
\hline
\end{tabular}

Table 3. Plasmids in isolates of B. globosum

Plasmid profiles are shown in Figs 1 and 4.

$\begin{array}{lrrrrrr}\text { Source of sample } & \overbrace{\text { Samples }}^{\text {No. examined }} & \text { Isolates } & & \text { D1 } & \text { D2 } & \text { D3 } \\ \text { Rat faeces } & 24 & 42 & 2 & 10 & 1 \\ \text { Calf faeces } & 8 & 14 & 0 & 1 & 1 \\ \text { Rabbit faeces } & 10 & 14 & 4 & 0 & 0 \\ \text { Lamb faeces } & 7 & 10 & 0 & 1 & 1 \\ \text { Chicken faeces } & 12 & 13 & 3 & 0 & 0 \\ \text { Piglet faeces } & 5 & 9 & 0 & 0 & 0 \\ \text { Infant faeces } & 2 & 3 & 0 & 0 & 0 \\ \text { Rumen of cattle } & 6 & 14 & 1 & 0 & 1 \\ \text { Sewage } & 10 & 10 & 1 & 1 & 0 \\ \text { Totals } & 84 & 129 & 11 & 13 & 4\end{array}$

Plasmids in bifidobacteria isolated from honey bees

The two remaining species in which plasmids were detected, $B$. asteroides and $B$. indicum, are specific inhabitants of the hind-gut of honey bees; the former is isolated almost exclusively from the intestines of western honey bees, while the latter is found only in the hind-gut of asiatic bees 


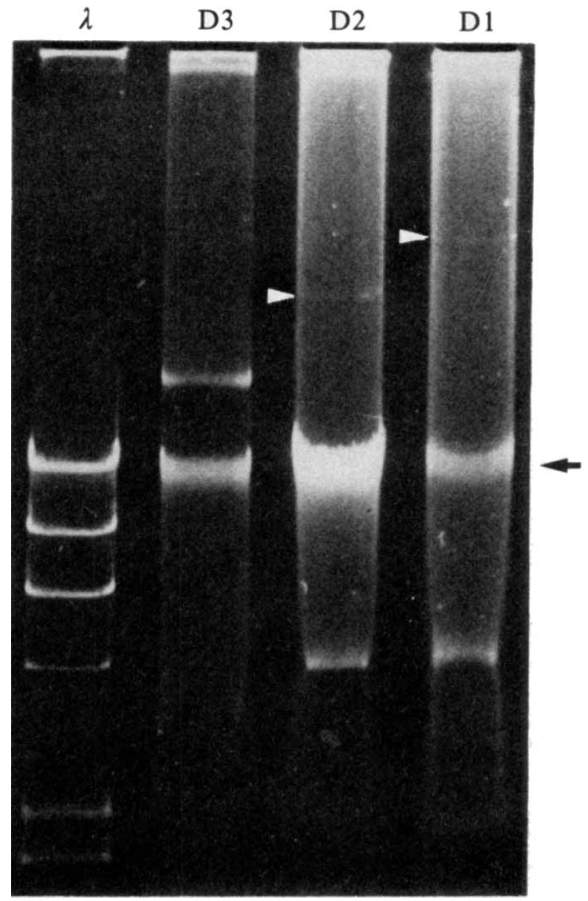

Fig. 4. Agarose gel electrophoresis using $8 \mathrm{~mm}$ wells, of plasmids from $B$. globosum. Letters above the lanes refer to plasmid profiles in Fig. 1 and Table 3. The strains used were: $B$. globosum D3, T19 (from rat faeces); D2, T58 (from rat faeces); D1, RA27 (from rabbit faeces). $\lambda$, lane containing HindIIIrestricted phage $\lambda$ DNA. Faint bands are indicated by white arrows. Residual chromosomal DNA is indicated by a black arrow.

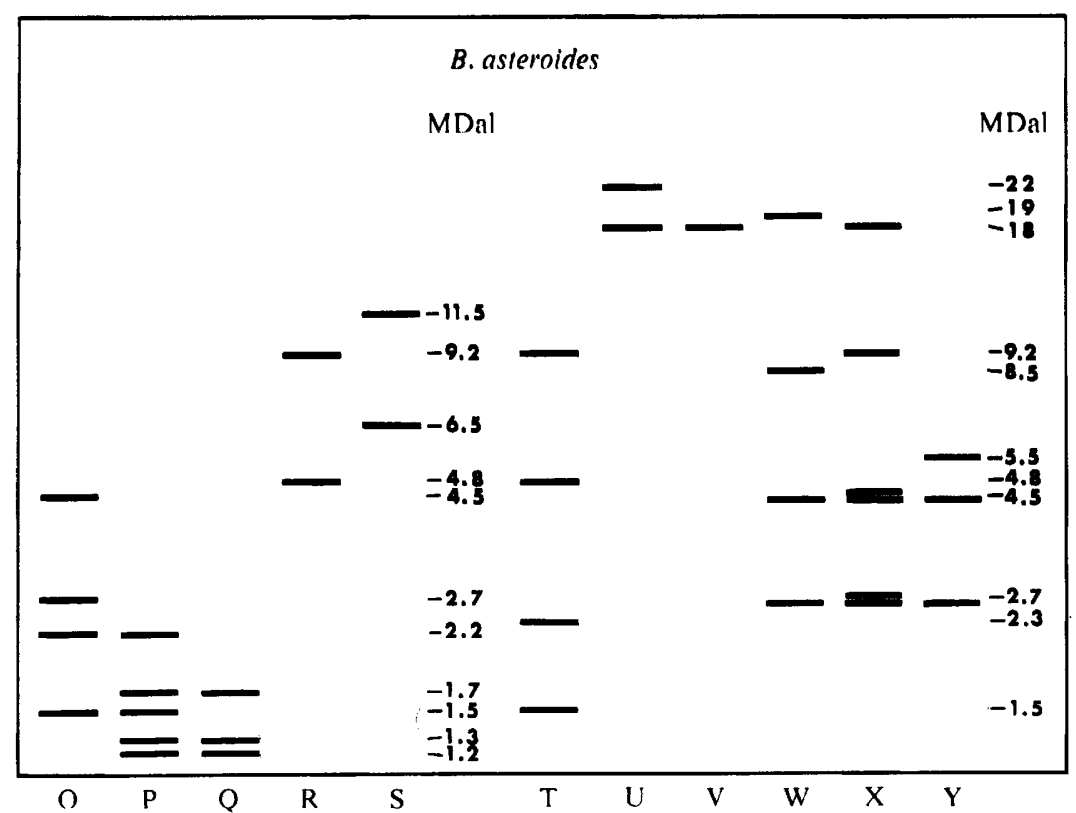

Fig. 5. Diagrammatic representation of the plasmid profiles (indicated by letters) less frequently found in $B$. asteroides. 


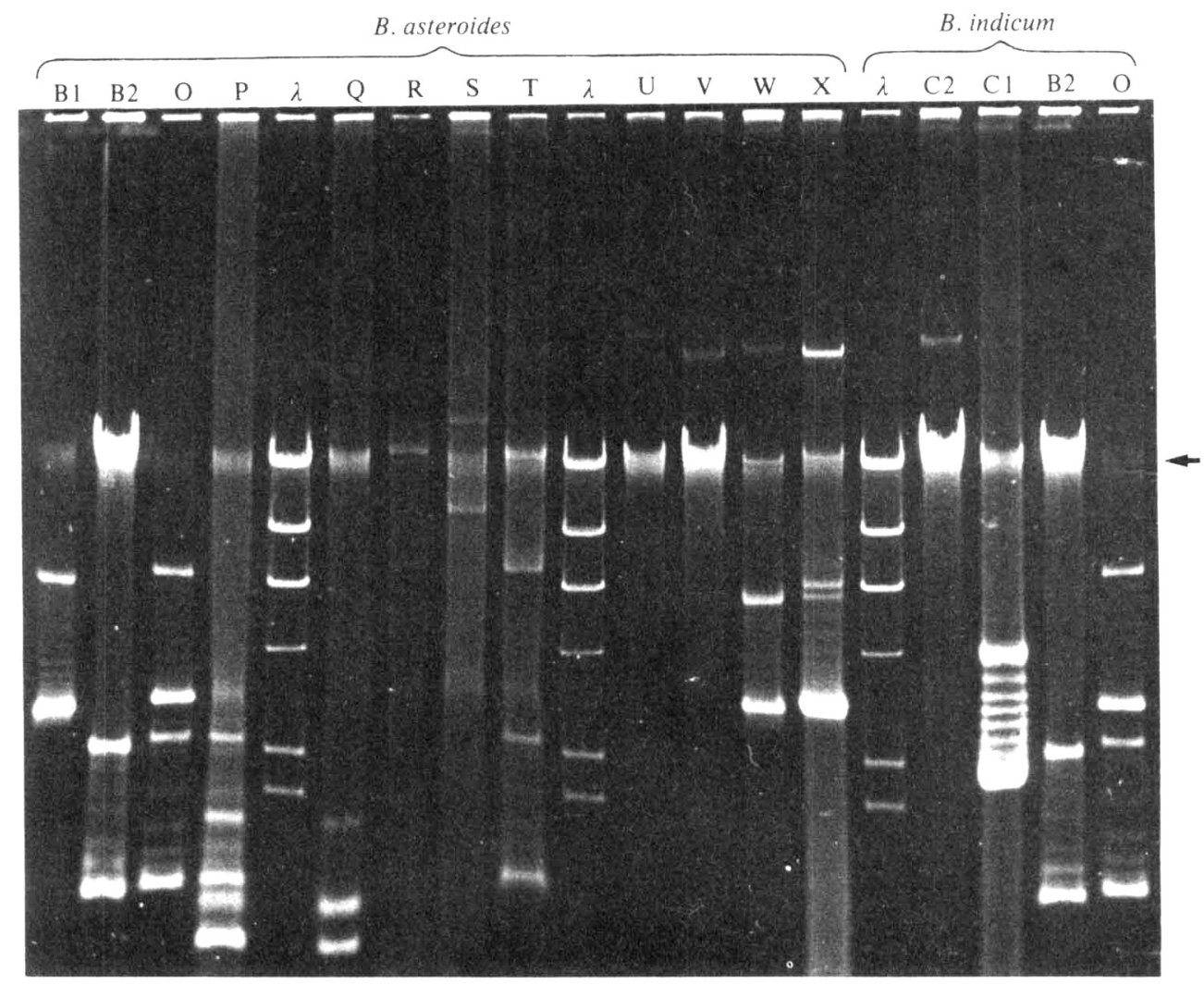

Fig. 6. Agarose gel electrophoresis of plasmids from strains of B. asteroides and B. indicum. Letters above the lanes refer to plasmid profiles used in Tables 4 and 5 and Figs $I$ and 5 . The strains used were: B. asteroides B1, C350; B2, C503; O, C359; P, C367/1; Q, C365/1; R, C236; S, C658; T, C212; U, C333; V, C690; W, C353; X, C682; B. indicum C2, C576; C1, C515; B2, C503; O, C450. $\lambda$, lanes containing HindIII-restricted phage $\lambda$ DNA. Residual chromosomal DNA is arrowed.

(Scardovi \& Trovatelli, 1969). These species do not have any significant homology with any other species of the genus (Scardovi et al., 1971) and are evolutionarily quite divergent from them, as suggested by the immunological properties of their transaldolases (Sgorbati, 1979; Sgorbati \& London, 1982). The two species display plasmid profiles which are distinct from those of $B$. longum and B. globosum. In addition, the profiles of $B$. indicum are, for the most part, different from those of $B$. asteroides (Fig. 1).

Strains of $B$. asteroides were isolated from bees received from 15 countries, and among the 74 plasmid-containing isolates studied, 14 different plasmid profiles were observed (Figs 1, 5, and 6). The ladder effect seen in some lanes of Fig. 6 is probably due to the activity of a topoisomerase (Cozzarelli, 1980), with the resulting faint bands representing different degrees of supercoiling of the same plasmid. These bands were therefore omitted from the plasmid profiles (Figs 1 and 5).

The occurrence and distribution of the different plasmid profiles in B. asteroides isolates did not correlate with the geographical areas in which the host bees were raised, as seen in Table 4. Four profiles predominated, accounting for over $75 \%$ of the plasmid-containing isolates. Profiles W, B1, B2 and B3 were observed among isolates from four, five, six and seven different countries, respectively. These results may be interpreted to suggest that the profiles $\mathrm{W}, \mathrm{B} 1, \mathrm{~B} 2$ and $B 3$ identify four strains of $B$. asteroides which have been widely disseminated throughout the world. Alternatively, particularly with regard to profile B3, the plasmids may be widely disseminated among strains of $B$. asteroides.

The 73 plasmid-containing isolates of $B$. indicum were all obtained from two species of honey 
Table 4. Plasmids in B. asteroides

Plasmid profiles are shown in Figs 1 and 6.

\begin{tabular}{|c|c|c|c|c|c|c|c|c|c|c|c|c|c|c|c|c|}
\hline \multirow[b]{3}{*}{ Honey bee } & \multirow[b]{3}{*}{ Country } & \multicolumn{15}{|c|}{ No. of isolates: } \\
\hline & & \multirow[b]{2}{*}{ Studied } & \multicolumn{14}{|c|}{ With plasmid profiles: } \\
\hline & & & B1 & B2 & B3 & $\mathrm{O}$ & $\mathbf{P}$ & Q & $\mathbf{R}$ & $S$ & $\mathrm{~T}$ & $\mathrm{U}$ & $\mathrm{V}$ & W & $\mathrm{X}$ & $\mathbf{Y}$ \\
\hline A. mellifera ligustica & Italy & 33 & $\cdot$ & 3 & 1 & $\cdot$ & $\cdot$ & • & • & . & . & - & - & 2 & $\cdot$ & • \\
\hline A. mellifera mellifera & $\begin{array}{l}\text { France } \\
\text { Norway }\end{array}$ & $\begin{array}{r}2 \\
10\end{array}$ & $\cdot$ & $\dot{\cdot}$ & $\cdot$ & $\dot{\cdot}$ & • & • & $\begin{array}{l}\cdot \\
\cdot\end{array}$ & $\dot{.}$ & $\dot{\cdot}$ & $\dot{.}$ & $\dot{.}$ & $\cdot$ & $\dot{\cdot}$ & $\dot{\bullet}$ \\
\hline A. mellifera caucasica & $\begin{array}{l}\text { Denmark } \\
\text { Bulgaria } \\
\text { Soviet Union }\end{array}$ & $\begin{array}{r}5 \\
8 \\
14\end{array}$ & $\dot{.}$ & $\dot{5}$ & $\begin{array}{l}1 \\
\cdot \\
\cdot\end{array}$ & $\dot{\dot{1}}$ & $\dot{\bullet}$ & $\dot{\cdot}$ & $\dot{\dot{ }} \cdot$ & $\dot{.}$ & $\dot{\cdot}$ & $\dot{1}$ & $\dot{.}$ & $\dot{\bullet}$ & $\dot{\cdot}$ & $\begin{array}{l}1 \\
\cdot \\
\cdot\end{array}$ \\
\hline A. cerana & Philippines & 9 & $\cdot$ & 4 & $\cdot$ & $\cdot$ & · & $\cdot$ & $\cdot$ & $\cdot$ & - & . & $\cdot$ & $\cdot$ & - & $\cdot$ \\
\hline A. mellifera & $\begin{array}{l}\text { Scotland } \\
\text { England } \\
\text { Germany } \\
\text { Norway } \\
\text { Belgium } \\
\text { Poland } \\
\text { Yugoslavia } \\
\text { Greece } \\
\text { Soviet Union } \\
\text { Czechoslovakia } \\
\text { Philippines }\end{array}$ & $\begin{array}{r}5 \\
24 \\
28 \\
8 \\
2 \\
8 \\
21 \\
6 \\
4 \\
4 \\
34\end{array}$ & $\begin{array}{r}. \\
2 \\
10 \\
1 \\
\dot{\cdot} \\
\dot{1} \\
\dot{1} \\
\dot{\cdot}\end{array}$ & $\begin{array}{l}4 \\
1 \\
2 \\
\dot{\cdot} \\
\dot{\cdot} \\
\dot{\cdot} \\
\dot{\cdot} \\
\dot{\cdot} \\
\dot{\cdot}\end{array}$ & $\begin{array}{l}\dot{1} \\
1 \\
\dot{5} \\
\dot{3} \\
5 \\
1 \\
\dot{.} \\
\dot{.}\end{array}$ & $\begin{array}{l}\dot{.} \\
\dot{.} \\
\dot{.} \\
\dot{.} \\
\dot{.} \\
\dot{.} \\
\dot{1}\end{array}$ & $\begin{array}{l}\dot{.} \\
\dot{.} \\
\dot{.} \\
\dot{.} \\
\dot{.} \\
\dot{.}\end{array}$ & $\begin{array}{l}\dot{.} \\
\dot{.} \\
\dot{.} \\
\dot{.} \\
\dot{.} \\
\dot{.} \\
\dot{.}\end{array}$ & $\begin{array}{l}\dot{.} \\
\dot{1} \\
\dot{.} \\
\dot{.} \\
\dot{.} \\
\dot{.}\end{array}$ & $\begin{array}{l}\dot{b} \\
\dot{.} \\
\dot{.} \\
\dot{.} \\
\dot{5}\end{array}$ & $\begin{array}{l}\dot{.} \\
\dot{2} \\
\dot{.} \\
\dot{.} \\
\dot{.} \\
\dot{.} \\
\dot{.}\end{array}$ & $\begin{array}{l}\dot{.} \\
\dot{.} \\
\dot{.} \\
\dot{.} \\
\dot{\cdot} \\
\dot{.} \\
\dot{.}\end{array}$ & $\begin{array}{l}\dot{.} \\
\dot{.} \\
\dot{.} \\
\dot{.} \\
\dot{.} \\
\dot{.} \\
\dot{4}\end{array}$ & $\begin{array}{l}\dot{.} \\
\dot{.} \\
\dot{.} \\
\dot{.} \\
\dot{.} \\
\dot{1} \\
2\end{array}$ & $\begin{array}{l}\dot{ } \\
\dot{\cdot} \\
\dot{\cdot} \\
\dot{\cdot} \\
\dot{\cdot} \\
\dot{1}\end{array}$ & $\begin{array}{l}\dot{ } \\
\dot{.} \\
\dot{.} \\
\dot{b} \\
\dot{.} \\
\dot{.} \\
\dot{.}\end{array}$ \\
\hline $\begin{array}{l}\text { Total no. of isolates } \\
\text { No. of countries repre }\end{array}$ & sented by profile & 225 & $\begin{array}{r}16 \\
5\end{array}$ & $\begin{array}{r}20 \\
6\end{array}$ & $\begin{array}{r}13 \\
7\end{array}$ & $\begin{array}{l}2 \\
2\end{array}$ & $\begin{array}{l}1 \\
1\end{array}$ & $\begin{array}{l}1 \\
1\end{array}$ & $\begin{array}{l}1 \\
1\end{array}$ & $\begin{array}{l}3 \\
1\end{array}$ & $\begin{array}{l}2 \\
1\end{array}$ & $\begin{array}{l}1 \\
1\end{array}$ & $\begin{array}{l}4 \\
1\end{array}$ & $\begin{array}{l}7 \\
4\end{array}$ & $\begin{array}{l}1 \\
1\end{array}$ & $\begin{array}{l}2 \\
2\end{array}$ \\
\hline
\end{tabular}

Table 5. Plasmids in B. indicum

Plasmid profiles are shown in Figs 1 and 6.

\begin{tabular}{|c|c|c|c|c|c|c|}
\hline \multirow[b]{3}{*}{ Honey bee } & \multirow[b]{3}{*}{ Country } & \multicolumn{5}{|c|}{ No. of isolates: } \\
\hline & & \multirow[b]{2}{*}{ Studied } & \multicolumn{4}{|c|}{ With plasmid profiles: } \\
\hline & & & $\mathrm{Cl}$ & $\mathrm{C} 2$ & B2 & $\mathrm{O}$ \\
\hline A. dorsata & Philippines & 53 & 15 & 4 & 3 & 4 \\
\hline \multirow[t]{3}{*}{ A. cerana } & Philippines & 48 & 9 & 38 & 0 & 0 \\
\hline & Malaysia & 4 & 0 & 0 & 0 & 0 \\
\hline & Japan & 1 & 0 & 0 & 0 & 0 \\
\hline Totals & & 106 & 24 & 42 & 3 & 4 \\
\hline
\end{tabular}

bee, Apis dorsata and A. cerana, received from the Philippines. Nine of the plasmid-containing isolates obtained from $A$. cerana had profile $\mathrm{C} 1$, composed of three small plasmids, and 38 of these isolates harboured only a single $22 \mathrm{MDal}$ plasmid (C2; Table 5, Figs 1 and 6). Of the 26 plasmid-containing isolates from $A$. dorsata, 19 had either the $\mathrm{C} 1$ or the $\mathrm{C} 2$ plasmid complement. Seven of the $B$. indicum isolates from $A$. dorsata had plasmid profiles common among $B$. asteroides strains, namely $\mathbf{B} 2$ (three isolates) and $\mathrm{O}$ (four isolates).

The species $B$. indicum is distinguished from $B$. asteroides on the basis of DNA homology, morphology and transaldolase and 6-phosphogluconate dehydrogenase zymograms (Scardovi $e t$ al., 1979). The plasmid profiles of $90 \%$ of the $B$. indicum isolates were different from those of B. asteroides.

The plasmid complements of bacterial isolates, particularly the multi-plasmid profiles observed among many isolates of $B$. longum, $B$. asteroides and $B$. indicum, can serve as molecular markers for the identification of specific strains. Such profiles may help to establish the geo- 
graphical distribution of specific strains of $B$. asteroides, or the dissemination of particular strains of $B$. longum within a human population. The validity of plasmid profiles as taxonomic markers is dependent on the demonstration of homology between plasmids of the same size in different isolates, and this will be the subject of further investigations.

In addition to establishing the identity of plasmids within a profile, the homology studies are expected to identify identical plasmids in different profiles. This type of information may be invaluable in establishing evolutionary relationships and distances among strains of the same, as well as closely related species.

No phenotypic properties have been correlated with the presence of any of the plasmids in the four plasmid-containing species. There does not appear to be any correlation between carbohydrate fermentation ability and the presence of plasmids in isolates of B. longum or B. globosum. Biotypes of $B$. longum differing in their ability to ferment ribose, melezitose and gluconate were included in this study as well as $\boldsymbol{B}$. globosum strains capable of fermenting arabinose and xylose but not mannitol.

Since temperate phages may persist in the cell in an extrachromosomal state, so as to mimic plasmids (Lieb, 1970; Novick et al., 1976), one of us attempted to detect phages after UV or mitomycin $\mathrm{C}$ treatment in a number of plasmid-containing and plasmid-free strains of $\boldsymbol{B}$. longum. Many strains did liberate phage particles but no correlation with their plasmid complement was evident (B. Sgorbati, unpublished results).

Preliminary results seem to indicate a link between plasmids and tetracycline resistance in some strains of $B$. globosum. The existence of $\mathrm{R}$ plasmids in this species may be useful in establishing a genetic transfer system.

The authors are very grateful to Mrs Linda Lee for excellent technical assistance. B.S. was supported by a research grant from the Consiglio Nazionale delle Ricerche, Roma, Italia.

\section{REFERENCES}

Broda, P. (1979). Plasmids. Oxford \& San Francisco: W. H. Freeman.

Cozzarelli, N. R. (1980). DNA gyrase and the supercoiling of DNA. Science 207, 953-960.

Davies, F. L., Underwood, H. M. \& Gasson, M. J. (1981). The value of plasmid profiles for strain identification in lactic streptococci and the relationship between Streptococcus lactis 712, ML3 and C2. Journal of Applied Bacteriology, 51, 325-337.

DeManN, J. C., Rogosa, M. \& Sharpe, E. M. (1960). A medium for cultivation of lactobacilli. Journal of Applied Bacteriology 23, 130-135.

FaLKow, S. (1975). Infectious Multiple Drug Resistance. London: Pion.

LeBlaNC, D. J. \& LEE, L. N. (1979). Rapid screening procedure for detection of plasmids in streptococci. Journal of Bacteriology 140, 1112-1115.

LIEB, M. (1970). $\lambda$ mutants which persist as plasmids. Journal of Virology 6, 218-225.

Macrina, F. L., Kopecko, D. J., Jones, K. R., Ayers, D. J. \& MCCowen, S. M. (1978). A multiple plasmid-containing Escherichia coli strain: convenient source of size reference plasmid molecules. Plasmid 1, 417-420.

MatteuzZi, D. \& Crociani, F. (1973). Urease production and DNA homology in the species Bifidobacterium suis. Archiv für Mikrobiologie 94, 93-95.

Meyers, J. A., SANChez, D., Elwell, L. P. \& FalKow, S. (1976). Simple agarose gel electrophoretic method for the identification and characterization of plasmid deoxyribonucleic acid. Journal of Bacteriology 127, 1529-1537.

MITSUOKA, T. (1969). Vergleichende Untersuchungen über die Bifidobakterien aus dem Verdauungstrakt von Menschen und Tieren. Zentralblatt für Bakteriologie, Parasitenkunde, Infektionskrankheiten und Hygiene. Abteilung I, Originale 210, 52-64.

MitsuoKa, T. \& KaNEUCH, D. V. M. (1977). Ecology of the bifidobacteria. American Journal of Clinical Nutrition 30, 1799-1810.

Novick, R. P., Clowes, R. C., Cohen, S. N., Curtiss, R., DATTA, N. \& Falkow, S. (1976). Uniform nomenclature for bacterial plasmids: a proposal. Bacteriological Reviews 40, 168-189.

Poupard, J. A., Husain, I. \& Norris, R. F. (1973). Biology of the bifidobacteria. Bacteriological Reviews 37, 136-165.

Privitera, A., Dublanchet, A. \& Sebald, M. (1979). Transfer of multiple antibiotic resistance between subspecies of Bacteroides fragilis. Journal of Infectious Diseases 139, 97-101.

REUTER, G. (1963-64). Vergleichende Untersuchungen über die Bifidus-Flora im Säuglings- und Erwachsenenstuhl. Zentralblatt für Bakteriologie, Parasitenkunde, Infektionskrankheiten und Hygiene. Abteilung I Originale 191, 486-507.

Rogosa, M. (1974). Genus Bifidobacterium. In Bergey's Manual of Determinative Bacteriology, 8th edn, pp. 669-676. Edited by R. E. Buchanan \& N. E. Gibbons. Baltimore: Williams \& Wilkins.

SCARDOVI, V. (1981). The genus Bifidobacterium. In The Prokaryotes. A Handbook on Habitats, Isolation, and Identification of Bacteria, pp. 1951-1961. Edited by M. P. Starr, H. Stolp, H. G. Trüper, A. Balows \& H. G. Schlegel. New York: Springer.

SCARDOVI, V.\& TROVATELII, L. D. (1969). New species 
of bifid bacteria from Apis mellifica L. and Apis indica $\mathrm{F}$. A contribution to the taxonomy and biochemistry of the genus Bifidobacterium. Zentralblatt für Bakteriologie, Parasitenkunde, Infektionskrankheiten und Hygiene. Abteilung 2 123, 64-88.

Scardovi, V. \& Trovatelli, L. D. (1974). Bifidobacterium animalis (Mitsuoka) comb. nov. and the 'minimum' and 'subtile' groups of new bifidobacteria found in sewage. International Journal of Systematic Bacteriology 24, 21-28.

Scardovi, V., Trovatelli, L. D., Zani, G., Crociani, F. \& MatTeuzzI, D. (1971). Deoxyribonucleic acid homology relationships among species of the genus Bifidobacterium. International Journal of Systematic Bacteriology 21, 276-294.

Scardovi, V., Casalicchio, F. \& Vincenzi, N. (1979). Multiple electrophoretic forms of transaldolase and 6-phosphogluconate dehydrogenase and their relationships to the taxonomy and ecology of bifidobacteria. International Journal of Systematic Bacteriology 29, 312-329.
Sgorbati, B. (1979). Preliminary quantification of immunological relationships among the transaldolases of the genus Bifidobacterium. Antonie van Leeuwenhoek 45, 557-564.

SGORBATI, B. \& London, J. (1982). Demonstration of phylogenetic relatedness among members of the genus Bifidobacterium using the enzyme transaldolase as an evolutionary marker. International Journal of Systematic Bacteriology 32, 37-42.

Skerman, V. B. D., McGowan, V. \& Sneath, P. H. A. (1980). Approved lists of bacterial names. International Journal of Systematic Bacteriology 30, 225420.

Tally, F. P., Snydman, D. R., Gorbach, S. L. \& Malamy, M. H. (1979). Plasmid mediated transferable resistance to clindamycin and erythromycin in Bacteroides fragilis. Journal of Infectious Diseases 139, 83-88.

WelCh, R. A., Jones, K. R. \& MACRINA, F. L. (1979). Plasmid-mediated conjugational transfer of lincosamide-macrolide resistance in Bacteroides. Plasmid 2, 261-268. 